\title{
AGROCLIMATIC CONDITIONS IN BULGARIA AND AGRICULTURAL ADAPTATION
}

\author{
Valentin Kazandjiev ${ }^{1}$, Marek Degórski², Krzysztof Błażejczyk ${ }^{2}$, Veska Georgieva ${ }^{1}$ \\ ${ }^{1}$ National Institute of Meteorology and Hydrology \\ Bulgarian Academy of Sciences \\ 66 Tsarigradsko shausse, 1784 Sofia, Bulgaria \\ valentin.kazandjiev@meteo.bg, veska.georgieva@meteo.bg \\ 2 Institute of Geography and Spatial Organization \\ Polish Academy of Sciences \\ Twarda 51/55, 00-818 Warsaw, Poland \\ m.degor@twarda.pan.pl,k.blaz@twarda.pan.pl
}

\begin{abstract}
The sole factors of major importance to Bulgaria's agrarian output are temperature, and water probability. Between these two factors it is the component relating to soil moisture that proves more limiting. Probabilities of occurrence of water and of given temperatures are estimated by reference to summed temperatures and total rainfall, but also in relation to certain more specific indicators. Heat conditions and heat resources can be summed up by reference to the continuity of the vegetation period or growing season, which are limited for each type of plant, with thresholds for each crossed over the spring-autumn period in relation to biological minima. In the case of agricultural crops in Bulgaria, the biological minima are taken to be: $5^{\circ} \mathrm{C}$ - for wheat, barley, oats, peas, lentils and sunflowers; $10^{\circ} \mathrm{C}$ for corn, haricot beans and soybeans, and $15^{\circ} \mathrm{C}$ for cotton, vegetables and other spring cultures. The durations of cold and warm periods are of course interrelated characteristics. In the first period a key further issue is to determine the number of days with snow fall and with snow cover, these being fundamental to the shaping of soil-moisture reserves after the spring snow melt. Defining regions with thermal stress during the vegetation season is a further priority in describing agroclimatic conditions. Values indicative of limitations on crop growth would be one or more periods of at least 10 consecutive days with maximal air temperature over $35^{\circ} \mathrm{C}$. Temperatures over $28^{\circ} \mathrm{C}$ are considered stresses that slow growth, and may even destroy plants if heat stress develops. The components most limiting the growth, development and formation of yields from agricultural crops are conditions as regards moisture represented in relation to atmospheric and soil moisture. The most apparent indicator is the annual total rainfall, or else the rainfall total in periods with average daily temperatures over 5 or over $10^{\circ} \mathrm{C}$. A cross correlation matrix between the meteorological elements upon which evapotranspiration depends, i.e. air temperature, relative air humidity, wind speed and vapour pressure deficit, is discussed. One of the ways of assessing the actual necessity for water is to consider the difference between rainfall totals and potential water use, i.e. evapotranspiration. The difference between these two variables presents the balance of atmospheric moisture (BAM). Values for the relationship between real and potential evapotranspiration were calculated for two potential vegetation sub periods: March-June (the period in which the yields from winter crops are shaped) and July-August (the period in which the yields for spring crops are shaped).
\end{abstract}

Keywords: agroclimatic conditions, agroclimatic resources, zoning of agroclimatic resources. 


\section{Introduction}

Just a few years ago, sceptics were still inclined to maintain that climate change was a fiction created by politicians, who were seeking to explain away some of their own failures by reference to it. In contrast, there is now much detailed research reporting the existence of marked changes in all elements of the climate (e.g. Degórski 2000, Salinger et al. 2000, Bański \& Błażejczyk 2006, Easterling et al. 2007, Trenberth 2011, Błażejczyk \& Żmudzka 2013). Indeed, evidence is now well-documented for all regions of the world, though there remain several key questions, such as:

- What is the magnitude of change?

- How may present changes be characterised and accounted for?

- What are the trends to changes?

- How will the changes impact upon agriculture?

- How can the effects of changes be mitigated and sustainable agriculture developed?

- What is the role of zoning to optimize the utilisation of agroclimatic resources?

Agriculture is a very important sector of most national economies and one that is highly dependent on climatic and weather conditions (Brandani et al. 2010, Dalla Marta et al. 2011, Kazandjiev et al. 2011). The main components to the aforementioned agroclimatic resources are overall temperatures and amounts of precipitation characteristic for a given period at a given location. Obviously appropriate thermal and water resources during the growing season are very important, though different plant species are known to have various requirements where the factors of temperature and precipitation are concerned. In general, cultivated plants can be divided into four groups from this point of view, where Group 1 refers to cool and temperate conditions (and crops would include spring wheat, beans and potatoes). Here with the temperature optimal for photosynthesis is of $15-20^{\circ} \mathrm{C}$. Group 2 in turn refers to crops of warm climates (e.g. soya, cotton and rice), with optimal temperature in this case being $25-30^{\circ} \mathrm{C}$. Group 3 refers to very warm climates with optimal temperature of $30-35^{\circ} \mathrm{C}$ (with suitable crops being proso, sorgo and sugar cane). Finally, Group 4 refers to temperate climates with optimal temperatures of $20-25^{\circ} \mathrm{C}$ (where crops include mountain species of sorgo and maize) (Bański \& Błażejczyk 2006).

Weather conditions are among the main factors determining the productivity of agricultural crops. In many cases, yields are determined by environmental conditions to the tune of about $80 \%$. Extreme weather events and climate anomalies thus have a strong impact, and can compromise yields and/or reduce the quality of output. Knowing the timing and amplitude of meteorological events and weather anomalies can nevertheless allow for effective planning of remedial activities. While the whole period since 1980 has been associated with more tangible climatic fluctuations and changes, of more serious consequences, the last 20 years in particular have seen extreme weather events become more frequent and increasingly destructive.

Against this background, the aims of the work described here have thus been: to discuss the dynamics and trends characterising temperature time series and the spatial distribution of average, maximal and minimal annual temperatures; to discuss the dynamics and trends associated with time series for rainfall and their spatial distribution; to investigate stress conditions caused by high temperatures and conditions of low or insufficient moisture; and finally to present a zoning of agroclimatic resources in Bulgaria, in relation to thermal and hygric parameters. 


\section{Material and methods}

All of the aforementioned objectives have been served through the use of data from climatic observations made at 60 stations of the meteorological network of the National Institute of Meteorology and Hydrology of the Bulgarian Academy of Sciences (NIMH-BAS). The data in question refer to the 35-year period 1971-2005, in regard to such meteorological elements and phenomena as: minimum and maximum temperatures, rainfall totals, relative air humidity, vapour pressure, sunshine duration and number of days with rain.

Another index which defines thermal conditions is the duration in days of the period during which average daily temperatures are above a defined value corresponding to the biological threshold for winter and spring crops. The number of days with average daily temperature above $5^{\circ} \mathrm{C}$ is considered to represent the duration of the Potential Vegetation Period (PVP). The came index for thermal conditions characterising the duration of the period with average daily temperatures above $10^{\circ} \mathrm{C}$ is in turn denoted as the Real Vegetation Period (RVP).

Stress conditions in agricultural can be affected by thermal and/or moisture conditions. Such conditions unfavourable for the cultivation of crops are classified in summary as:

- those affected by high temperatures (HT)

- those affected by a low quantity of rainfall (LR)

- those affected by a combination of high temperatures and low rainfall or dry spells (DS)

- those connected with a short growing season on account of a lack of soil moisture reserves corresponding to drought (DR).

At the same time, moisture conditions can be determined using a measure called the Balance of Atmosphere Moisturizing (BAM), whose analytical expression assumes the form of equation [1].

$$
B A M=\sum r-\sum E
$$

where: $\Sigma \mathrm{r}$ - sum of rainfall (mm) and $\Sigma \mathrm{E}$ - sum of evaporation (mm).

Hydrothermal conditions can also be presented using the drought index $\left(\mathrm{k}_{0}\right)$, with this presented in equation [2], as a relationship between totals for rainfall and evaporation during the growing season

$$
k_{0}=\sum r / \sum E
$$

These two formulae are typical agrometeorological indices where the description of moisture conditions is concerned. They are considered determinant factors in describing agroclimatic conditions in Bulgaria. However, another category type of this kind is the degree-days approximation used in the Selyaninov index (HTK). This is a hydro-thermal index, given that it combines daily values for temperature above $10^{\circ} \mathrm{C}$ and rainfall totals in a given calculation period [3].

$$
H T C=\frac{\sum^{r}}{0.1 \sum_{t>10^{\circ} \mathrm{C}} t}
$$

where:

$\Sigma \mathrm{r}$ - is the rainfall total $(\mathrm{mm})$ for the period with temperatures above $10^{\circ} \mathrm{C}$;

$\Sigma_{\mathrm{t}>10^{\circ} \mathrm{C}}$ - is the sum of temperatures above $10^{\circ} \mathrm{C}\left({ }^{\circ} \mathrm{C}\right)$ in the given month, season or year.

The Selyaninov hydro-thermal coefficient can assume values in the range 0.3-0.4 to 1.2-1.3 and more. The classification of hydro-thermal conditions is then related to the values obtained for HTC on a scale where $0.4-0.7$ denotes very dry, 0.7-1.0 dry, 1.0-1.3 insufficiently wet and $>1.3$ wet. 
An additional means of characterising hydrothermal conditions can be obtained if the relationship between real and potential evapotranspiration is investigated. The index in this case is the Crop Water Stress Index (CWSI) [4].

$$
C W S I=\frac{E T_{o}}{E T_{p}}
$$

\section{Results}

\section{Thermal conditions as an agrometeorological resource}

In the case of climatic conditions in Bulgaria, air temperatures do not constitute a limiting factor for agricultural production. The study period was characterised by an increase in average monthly, seasonal and annual values for temperature as related to the WMO reference period (1961-1990). Hence sums for active and effective temperatures will increase, while the frost-free period and growing season have been becoming longer. This fact is the basis for increased activity of winter crops even during the winter dormancy period, as well as increased consumption of soil water supplies in winter and a severe reduction of water resources at the beginning of the growing season in the spring. Higher temperatures are also associated with increased average daily values for evapotranspiration, and even more with a reduction of water reserves in the soil.

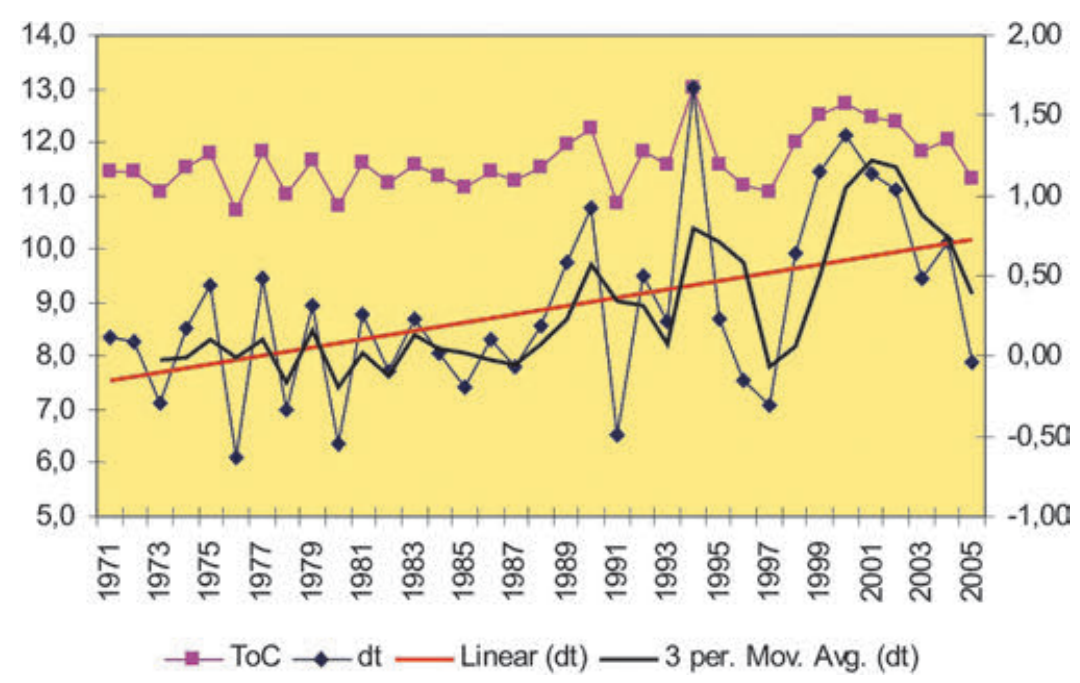

Figure 1. Variation in average annual temperature across Bulgaria in years of the 1971-2000 period (pink line), deviation in relation to 1961-1990 (blue), moving average of deviations (black) and trend line for deviations (red); left ' $y$ ' axis - annual average temperature in ${ }^{\circ} \mathrm{C}$, right ' $\mathrm{y}$ ' axis - values for temperature deviations in comparison with 1961-1990; 'x’ axis - years

The dynamics characterising average annual air temperatures in the period 1971-2000, differences from the reference period, a moving average for these differences and the trend characterising change are all presented in Figure 1. In the investigated period, average temperatures were up from 11 to $13^{\circ} \mathrm{C}$, or by $0.1-1.5^{\circ} \mathrm{C}$ in relation to the individual years of the $1961-1990$ period. There were 
nevertheless some years in which temperature differences as regards these comparisons of the periods were negative (i.e. 1972, 1976, 1980, 1990, 1992, 1995, 1996 and 1997). However, during all other years the differences in question are positive, suggesting that warming is observed. The key question then becomes the manner in which this warming is being distributed across the territory of Bulgaria.

Spatial structure characterising the temperature field is as presented in Figure 2, in which a ten-year trend for temperature change is depicted. As is clear, temperatures in the northern part of Bulgaria are displaying an upward trend, while the opposite is true of southern regions. The process is slow and there is even a tendency for average temperatures to decrease. These observations all correspond with what we know of the typical and actual circulation processes for the two parts of Bulgaria in question.

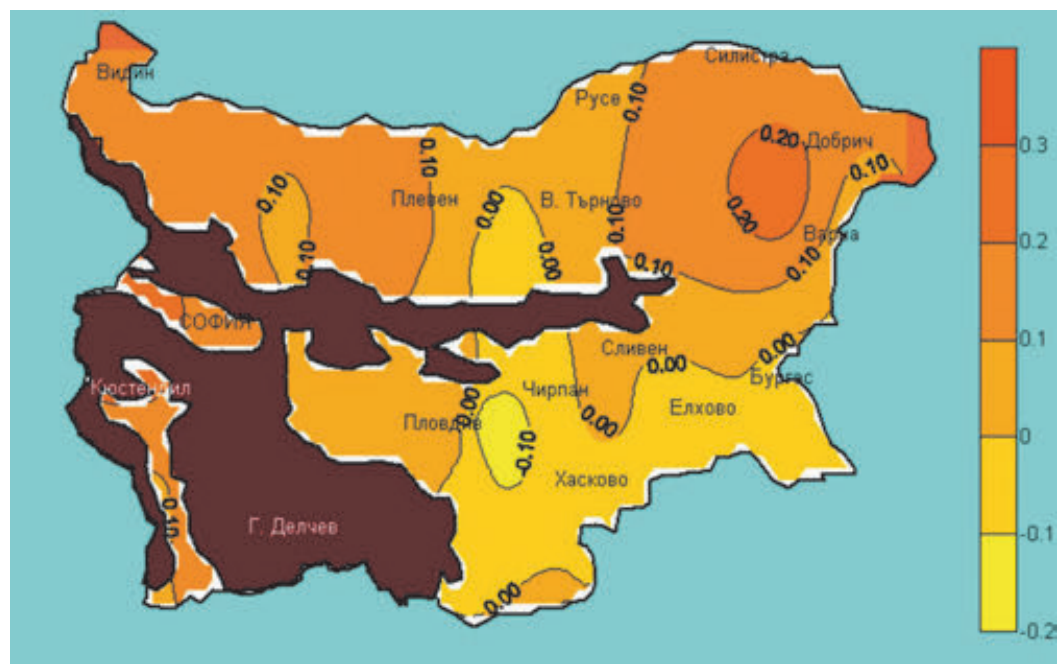

Figure 2. Spatial distribution of temperature change for the 1971-2000 period as compared with 1961-1990; the brown colour shows mountain regions (at altitudes above $1000 \mathrm{~m}$ ), which are not used for agriculture

The peculiarities to the spatial distribution of average temperatures are connected with the types of climate present in the different parts of the country, i.e. temperate continental in the north and transitional Mediterranean in the south. The absolute maximum temperature in the study period was the $44.4^{\circ} \mathrm{C}$ recorded on July 5th 2000 at the town of Yambol. The absolute maxima recorded for the north-eastern and west-central parts of Bulgaria are relatively much lower (Fig. 3). 


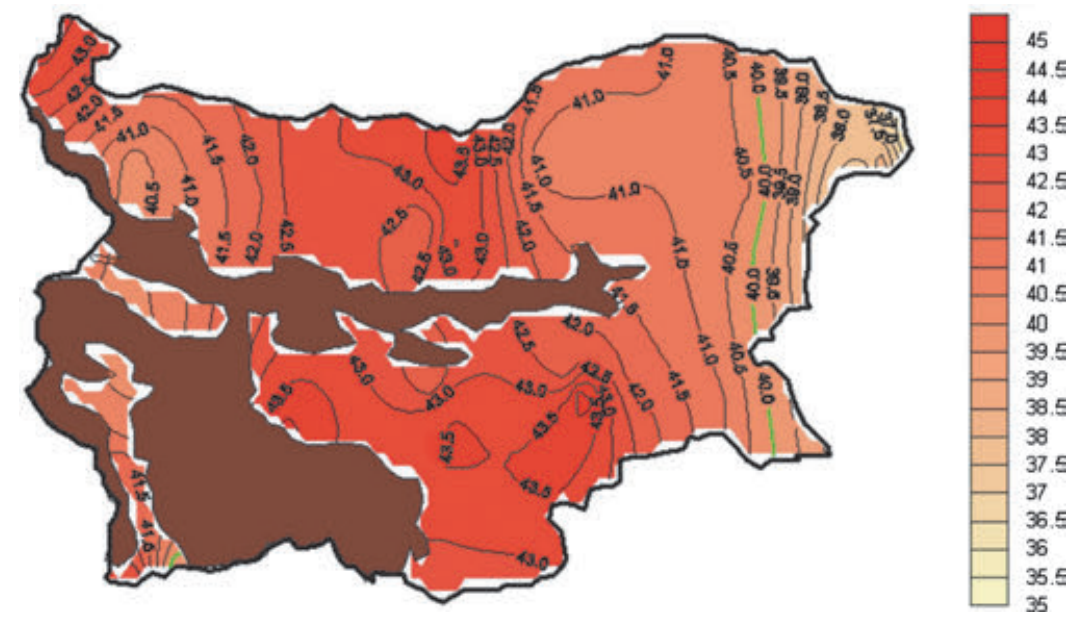

Figure 3. Spatial distribution of highest maximum air temperatures $\left({ }^{\circ} \mathrm{C}\right)$ recorded in different parts of Bulgaria in the years 1971-2000; the brown colour indicates mountain regions (of altitudes above $1000 \mathrm{~m}$ ) that are not used in agriculture

The point in the country recording the lowest minimum temperature during the period is situated in the north-west of Bulgaria (in Kneja), where a minimum temperature of $-29.3^{\circ} \mathrm{C}$ was measured on January $13^{\text {th }} 1985$ (Fig. 4). This means that the maximum possible amplitude as regards temperature in the studied years was of $73.7^{\circ} \mathrm{C}$, and is thus indicative of a continental type of climate.

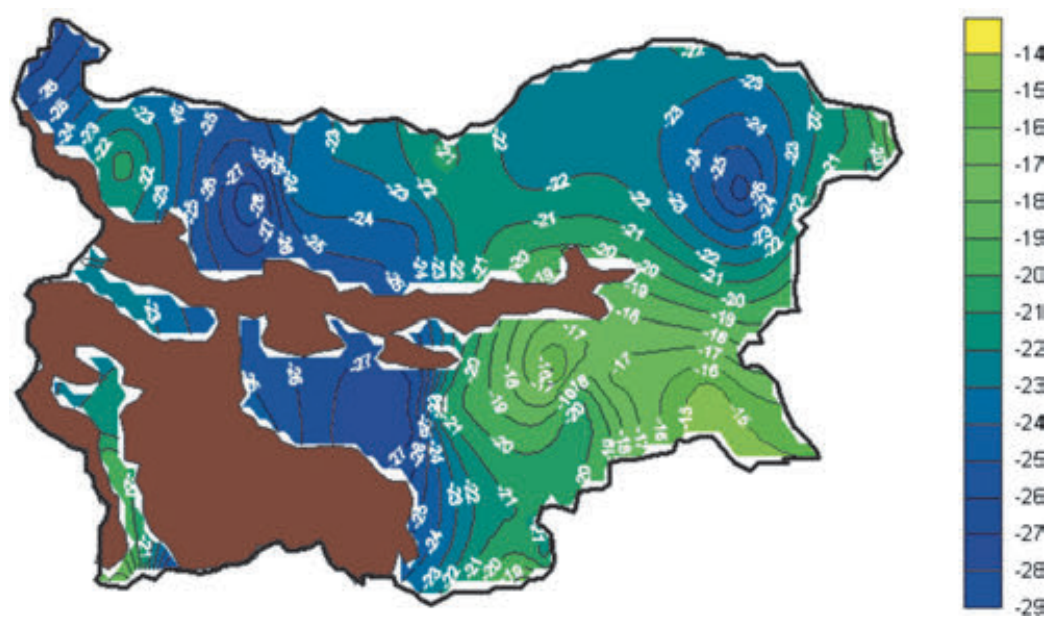

Figure 4. Spatial distribution of lowest minimum air temperatures $\left({ }^{\circ} \mathrm{C}\right)$ recorded for the $1971-2000$ period; the brown colour indicates mountain regions (of altitudes above $1000 \mathrm{~m}$ that are not used in agriculture

The duration of the Potential Vegetation Period (PVP) is important for winter crops. The average duration of this period in Bulgaria is 250-260 days. This is a period 7-10 days longer than its equivalent in the years 1961-1990 (Fig. 5). The duration of the Real Vegetation Period (RVP) is in turn of 200-220 days, on average (Fig. 6). 


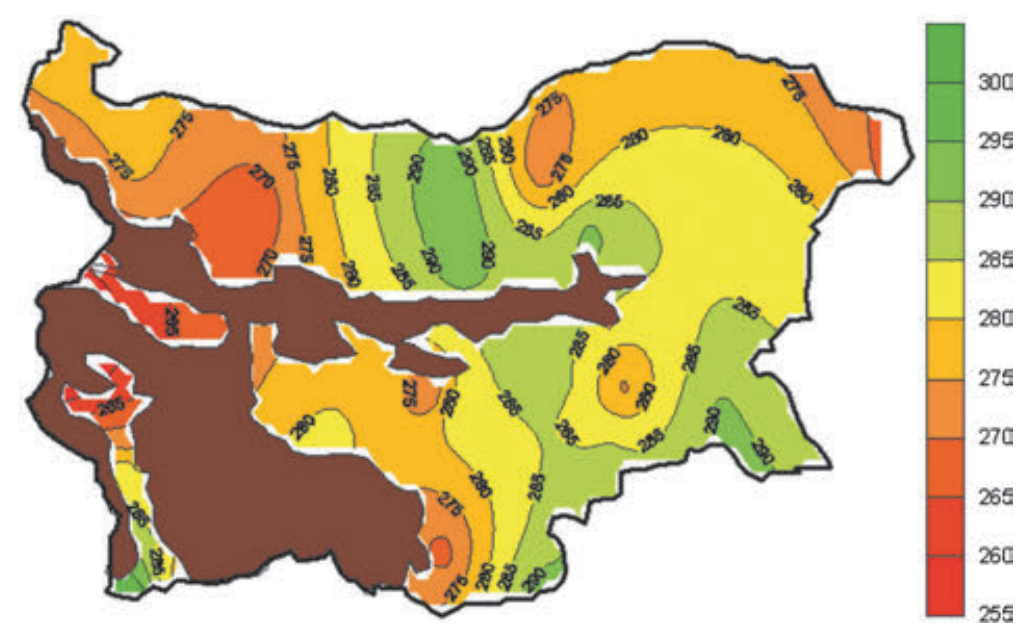

Figure 5. Duration of the Potential Vegetation Period (PVP), relating to days with an average daily air temperature above $5^{\circ} \mathrm{C}$ in the $1971-2000$ period; the brown colour marks mountain regions (of altitudes above $1000 \mathrm{~m}$ ) that are not used in agriculture

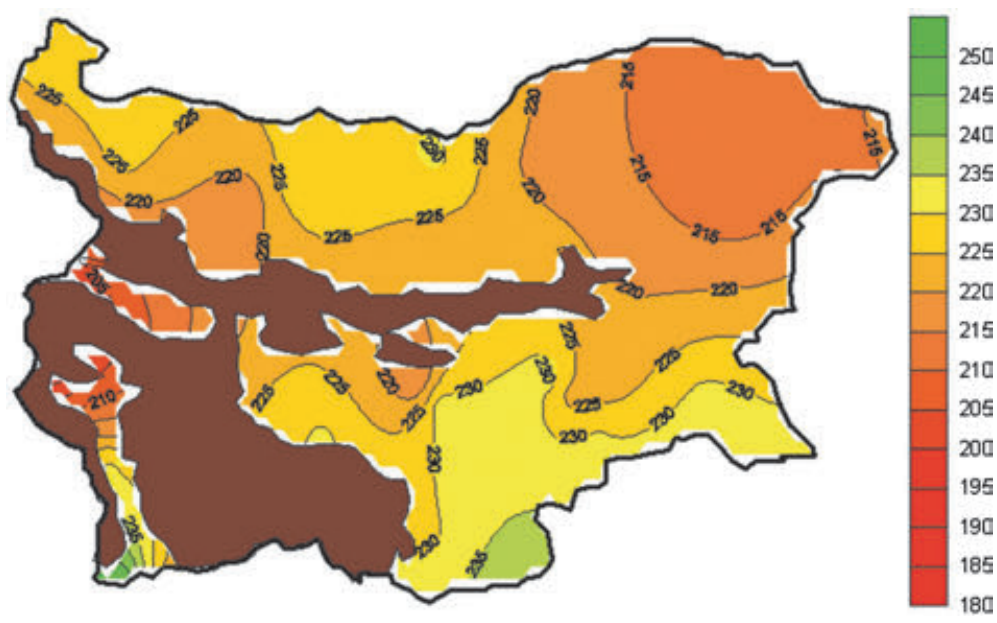

Figure 6. Duration of the Real Vegetation Period (RVP), relating to days with an average daily air temperature above $10^{\circ} \mathrm{C}$ in the $1971-2000$ period; the brown colour marks mountain regions (of altitudes above $1000 \mathrm{~m}$ ) that are not used in agriculture

\section{Rainfall as an agrometeorological resource}

Figure 7 presents average annual rainfall totals, differences in comparison with the 1961-1990 period, the moving average and a trend line for precipitation. Minimum rainfalls were measured in 1985, 1992, 1993 and 2000, while maximum quantities fell in 1979, 1980, 1987, 1991, 1995, 2002 and 2005. The spatial distribution of differences in rainfall between the studied and reference periods across Bulgaria reveals an irregular field (Fig. 8). 
In assessing moisture conditions of agroclimatic resources for PVP and RVP it is sufficient to calculate rainfall totals for specific time intervals limited by the crossing of temperature thresholds of 0,5 and $10^{\circ} \mathrm{C}$. The spatial distribution of these rainfalls was investigated, and the results show a decline in rainfall, as well as an enlargement of the area in the south and centre of the country in which totals are below average for the country (Fig. 9-12).

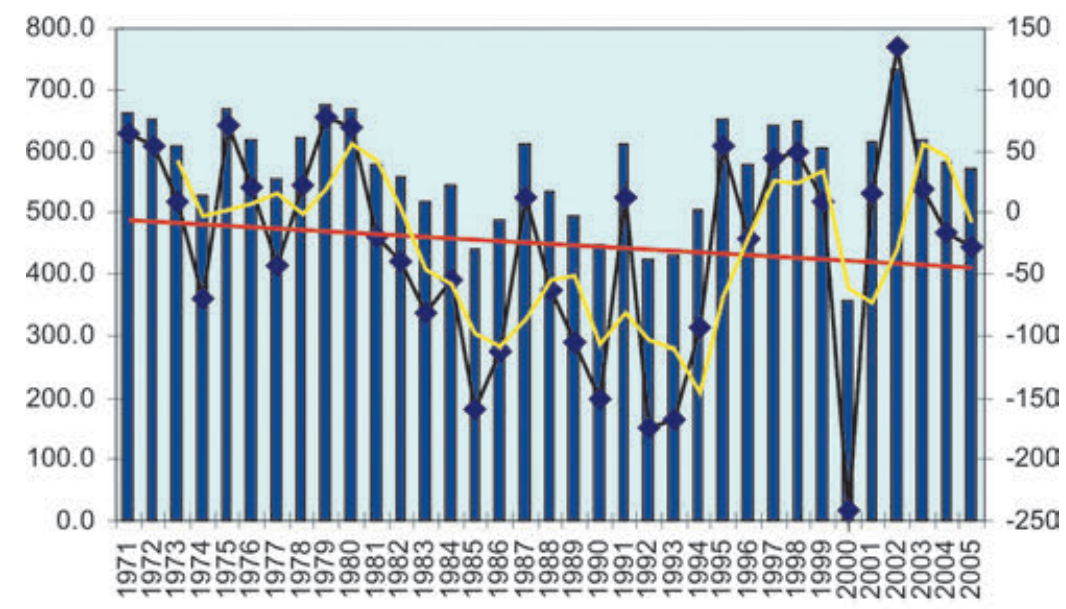

SR $\leadsto$ dr $\longrightarrow$ Linear (dr) $\longrightarrow 3$ per. Mov. Avg. (dr)

Figure 7. Annual rainfall totals for the 1971-2000 period (blue bars), deviations in comparison with the 1961-1990 period (blue line), moving average for the deviations (yellow line) and trend for the deviations (red line). The left ' $y$ ' axis correspond to annual totals and the right ' $y$ ' axis to deviations; while the ' $x$ ' axis presents the years of the period

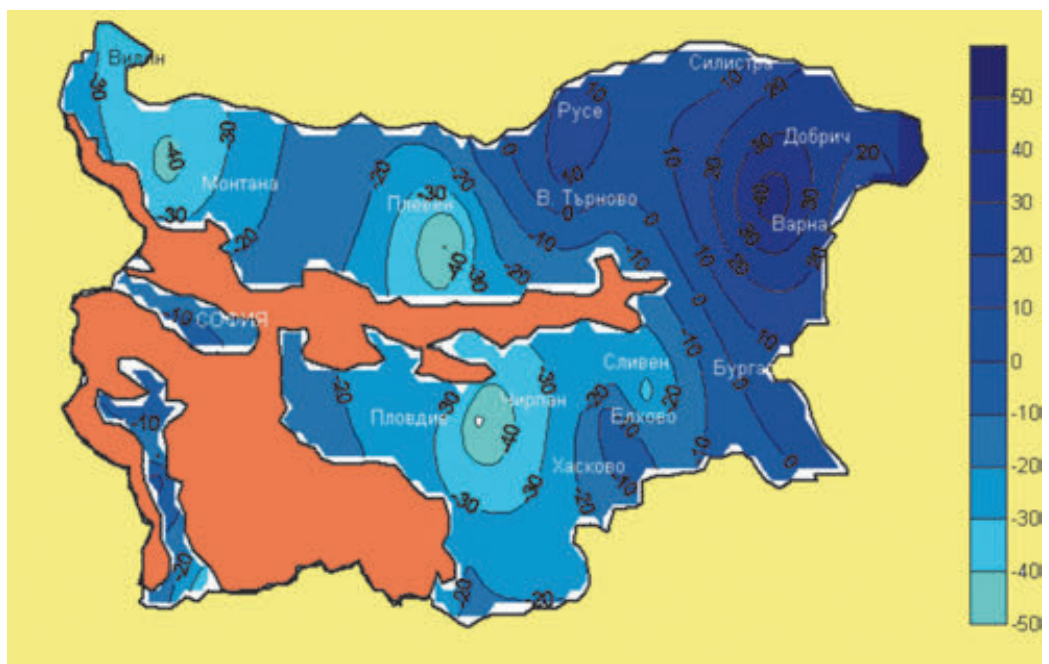

Figure 8. Spatial presentation of deviations (in mm) of annual totals of rain for the 1971-2000 period in relation to 1961-1990. Coloured orange are mountain regions (of altitudes above $1000 \mathrm{~m}$ ) not used in agriculture 


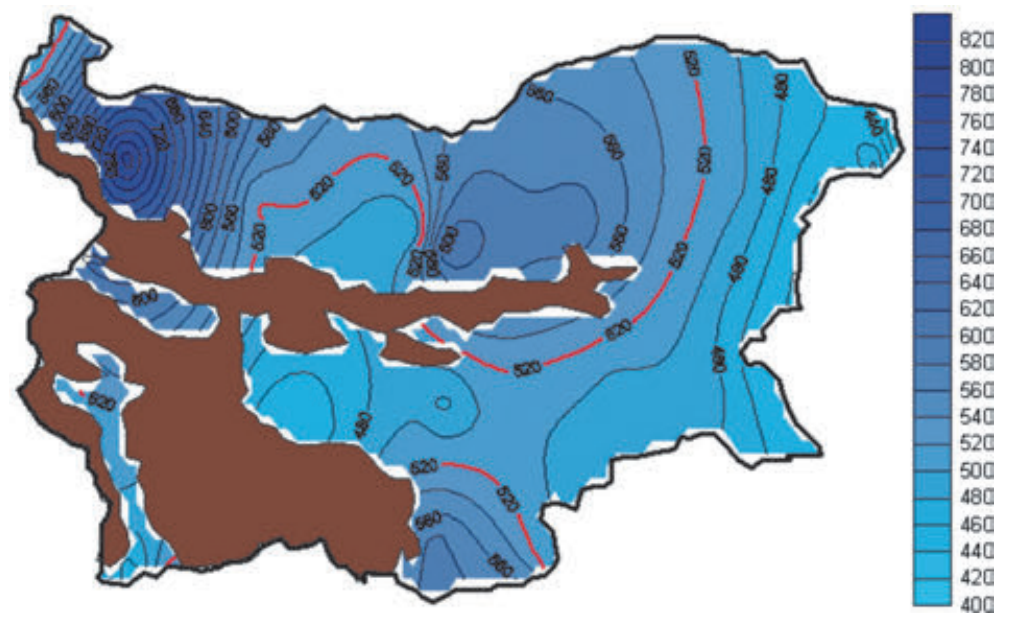

Figure 9. Rainfall totals during the 1971-2000 period; red line corresponds to average rainfall total for Bulgaria as a whole. Depicted in brown are mountain regions of altitudes above $1000 \mathrm{~m}$ not used in agriculture

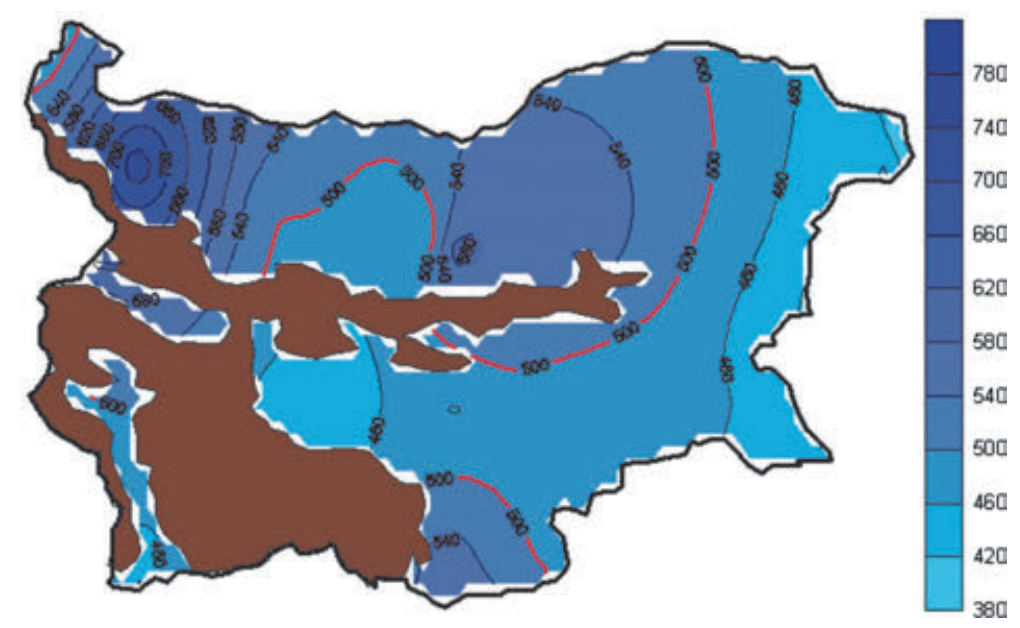

Figure 10. Spatial distribution of totals for rainfall in the 1971-2000 period, at times with an average daily air temperature above $0^{\circ} \mathrm{C}$. The red line corresponds to the average for the country. Depicted in brown are mountain regions of altitudes above $1000 \mathrm{~m}$ not used in agriculture 


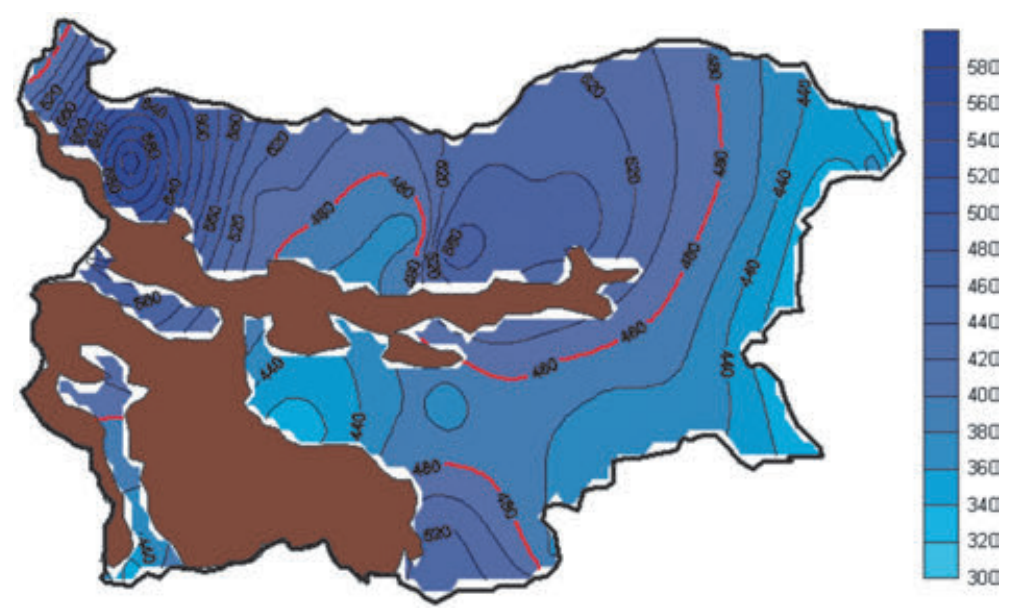

Figure 11. Spatial distribution of totals for rainfall in the 1971-2000 period, at times with an average daily air temperature above $5^{\circ} \mathrm{C}$. The red line corresponds to the average for the country. Depicted in brown are mountain regions of altitudes above $1000 \mathrm{~m}$ not used in agriculture

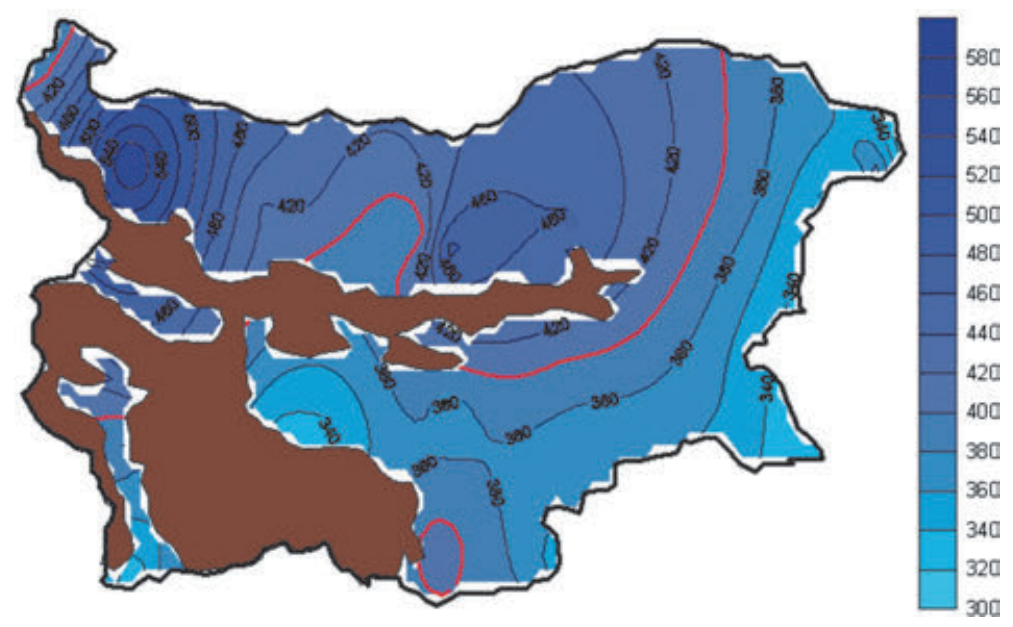

Figure 12. Spatial distribution of totals for rainfall in the 1971-2000 period, at times with an average daily air temperature above $10^{\circ} \mathrm{C}$. The red line corresponds to the average for the country. Depicted in brown are mountain regions of altitudes above $1000 \mathrm{~m}$ not used in agriculture

\section{Stress conditions}

Stress conditions for agriculture can be generated by thermal and/or moisture conditions. Particularly severe damage to crops is observed when stressing conditions occur in the period between 10 days before and 30 days after flowering. Exposure to short (10-day) periods of HT stress at flowering and 10 days before flowering cause maximum reductions in seed set and seed yield, while HT stress 
at post-flowering stages $(10,20$, and 30 days after flowering) leads to a seed-yield decrease, with a more marked reduction at early stages of seed development.

The frequency of occurrence of periods of three or more consecutive days with an average daily air temperature equal to or higher than $25^{\circ} \mathrm{C}$ (Fig. 13) was investigated, as were cases in which average daily temperature exceeded $25^{\circ} \mathrm{C}$ and/or relative air humidity was below $50 \%$ (Fig. 14). The analysis suggests a relatively stable distribution of such days in Bulgaria across the whole study period.

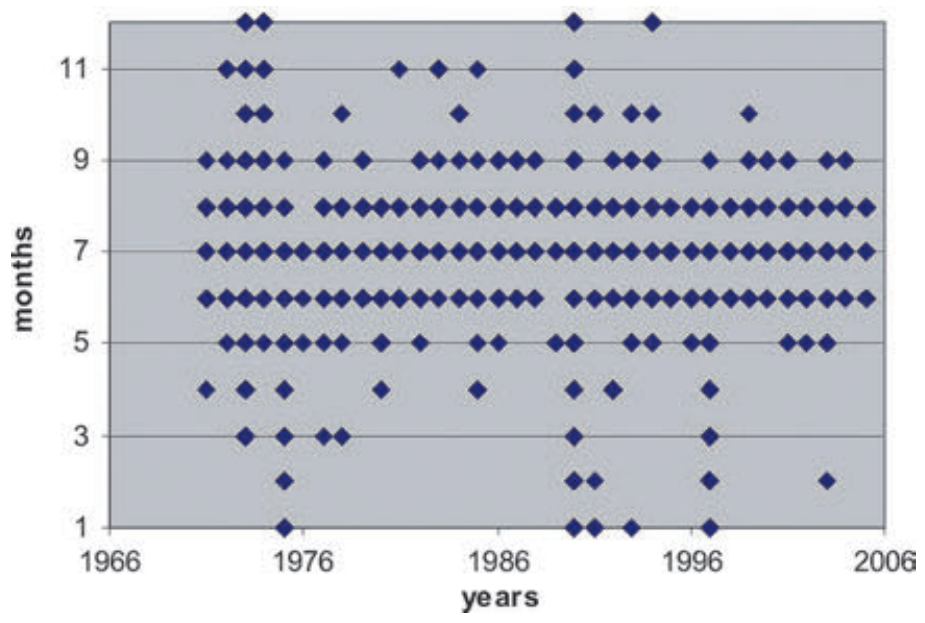

Figure 13. Occurrence of periods of three or more consecutive days with maximum daily temperature above $25^{\circ} \mathrm{C}$ in particular months in the years $1971-2005$

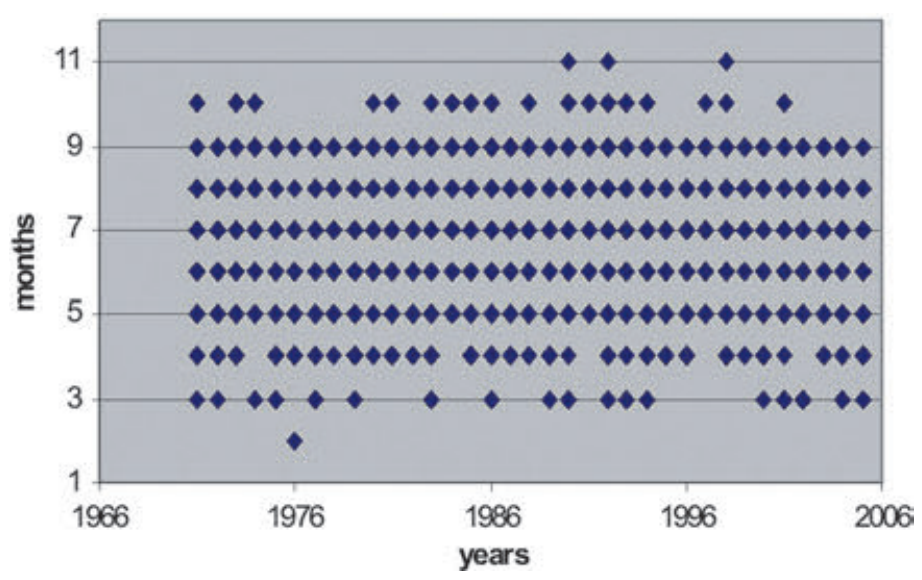

Figure 14. Occurrence of periods of three or more consecutive days with average daily temperature above $25^{\circ} \mathrm{C}$ and/or relative air humidity below $50 \%$ in particular months in the years 1971-2005

To determine hydrothermal conditions, use was made of a special matrix including three thermal categories (cold, warm and hot) and three moisture classes (dry, humid and wet) (Fig. 15). Use of such a generates nine clusters, of which two are empty in the case of Bulgaria (i.e. cold and dry, as well as hot and wet). Most cases fall within the warm and humid conditions cluster, corresponding with 
average annual temperatures in the $11-13^{\circ} \mathrm{C}$ range, and rainfall of $500-700 \mathrm{~mm}$. Moisture conditions with average annual rainfall below $500 \mathrm{~mm}$ are classified as dry, while totals above 700 and up to $900 \mathrm{~mm}$ categorise an area as wet.

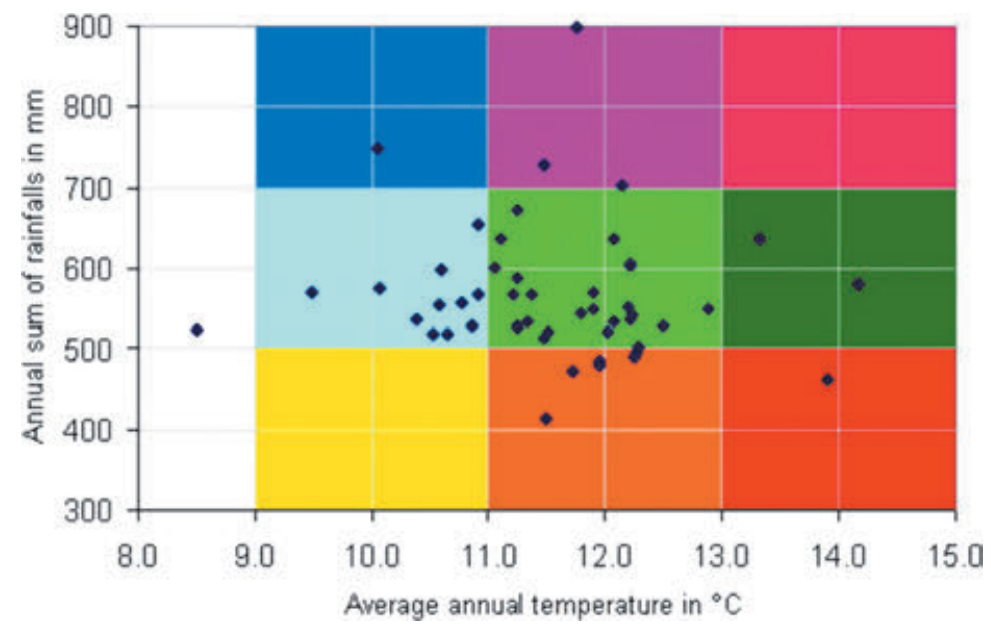

Figure 15. Agroclimatic conditions in relation to ranges of values for temperature or rainfall - cold and dry - yellow; cold and humid - light blue; cold and wet - dark blue; warm and dry - brown; warm and humid - light green; warm and wet - purple; hot and dry - red; hot and humid - dark green; hot and wet - rose

Aridity is a characteristic feature of climate relating to insufficiency of precipitation to maintain vegetation. For a single station, where the usual probability levels can be applied to choose particular threshold values in accordance with the hypothetical distribution of standard approximations of potential evapotranspiration, we can establish many types of aridity indices. The simplest way to approximate evaporation is using temperature alone, or a kind of temperature total and degree-days. The theoretical basic form of an aridity index is the evapotranspiration/precipitation ratio (Dunkel 2009).

\section{Hydrothermal conditions as a basis for zoning Bulgaria's agroclimatic resources}

Figure 16 presents the dynamics to and trend for the Balance of Atmosphere Moisture (BAM) for 4 representative stations and the whole period of investigation, considered year by year. The BAM assumes the highest negative values at the Sandanski station (south-west Bulgaria), where evaporation exceeds rain by more than $1200 \mathrm{~mm}$. By contrast, at the Shabla station, only very low values for evaporation were measured because both the amount of rainfall and the relative air humidity are relatively high. 


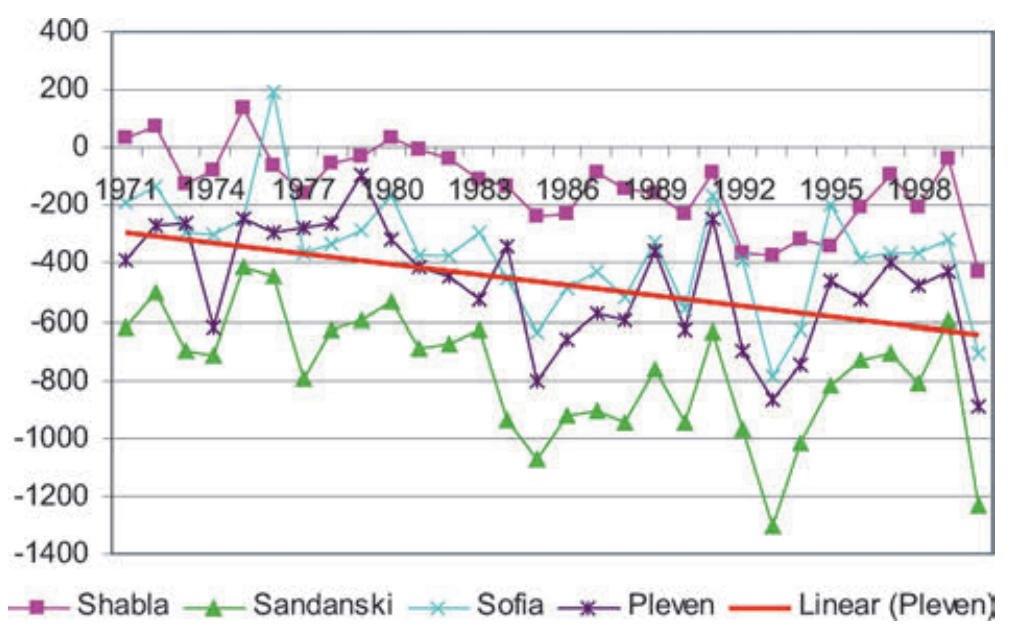

Figure 16. Average values and trend for the Balance of Atmosphere Moisture (BAM) at the Shabla, Sandanski, Sofia and Pleven stations, in the period 1971-2000 inclusive

In general, the drought index $\left(\mathrm{k}_{0}\right)$ assumes lowest values (above 0.5$)$ in north-east and west-central parts of Bulgaria. It is at the northern and southern edges of the country that values of the $\mathrm{k}_{0}$ index are lowest (Fig. 17).

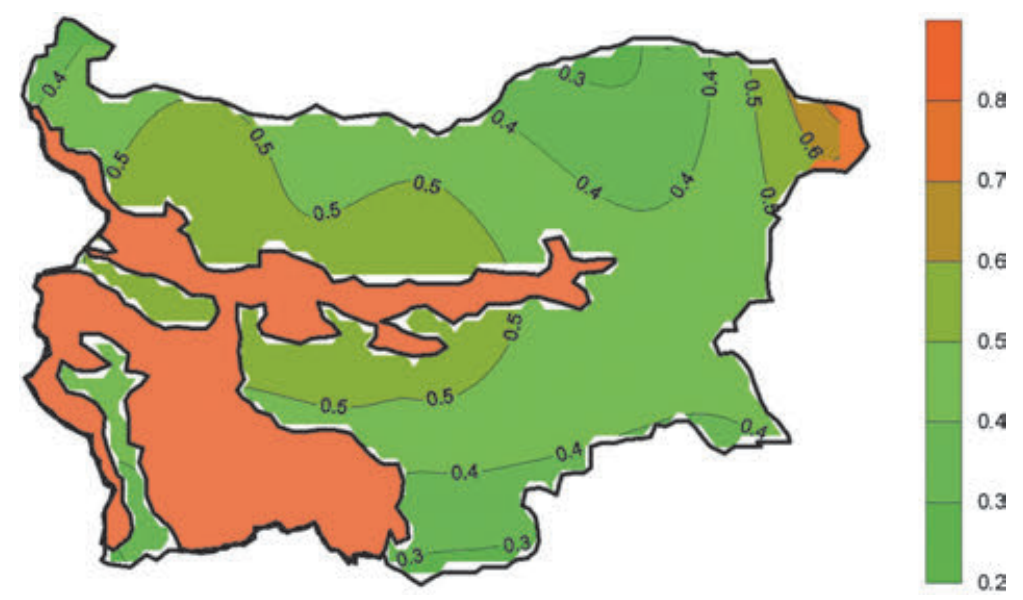

Figure 17. Spatial distribution of the drought index $\left(\mathrm{k}_{0}\right)$ over the territory of Bulgaria, 1971-2000; the orange colour depicts mountain regions (of altitudes above $1000 \mathrm{~m}$ ) not used in agriculture

The spatial distribution of values of the Selyaninov coefficient in the 1971-2000 period is presented in Figure 18. The driest regions are these with an HTK value below 0.7 - located in north-west, north-east and south-central parts of Bulgaria. These results entirely confirm those obtained using the BAM or drought indexes. 


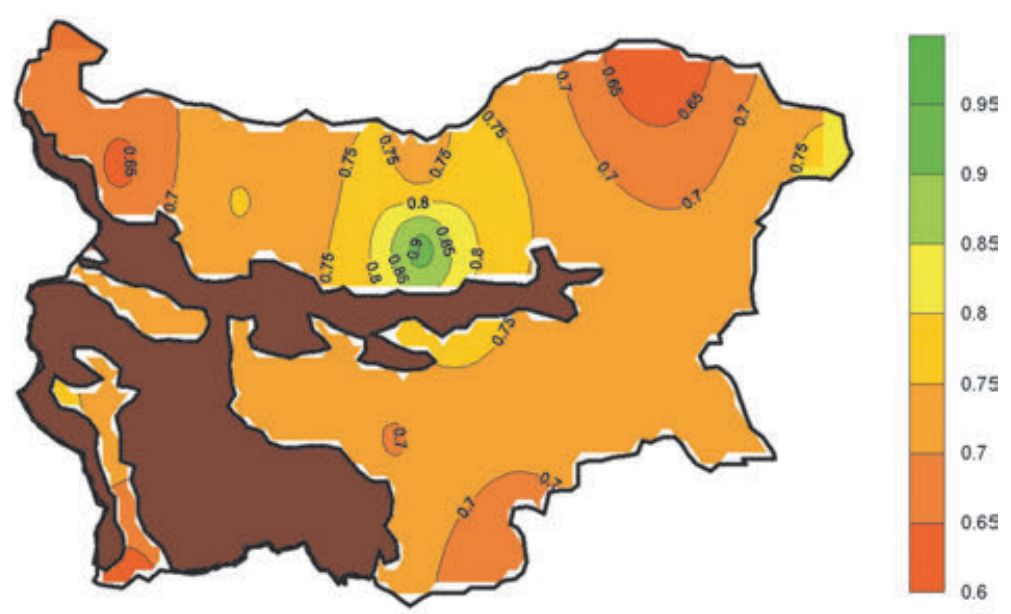

Figure 18. Spatial distribution across Bulgaria of moisture conditions expressed in terms of Selianinov's hydrothermal coefficient in relation to the 1971-2000 period; the brown colour denotes mountain regions (of altitudes above $1000 \mathrm{~m}$ ) not used in agriculture

The CWSI index was in turn calculated in relation to different periods corresponding with those in which the yields of winter and spring crops take shape, as well as the growing season as a whole (Fig. 19-21). Where the CWSI value is below 0.5 , conditions are very dry and it is necessary for crops to be irrigated.

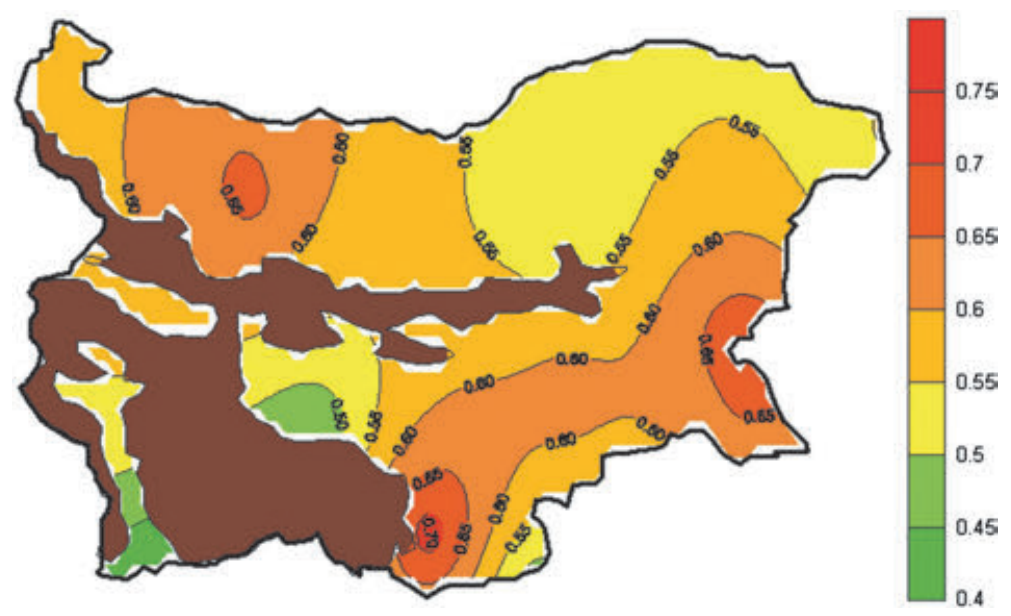

Figure 19. Spatial distribution of CWSI values for the April-June periods of the years 1971-2000 inclusive; the brown colour denotes mountain regions (of altitudes above $1000 \mathrm{~m}$ ) not used in agriculture 


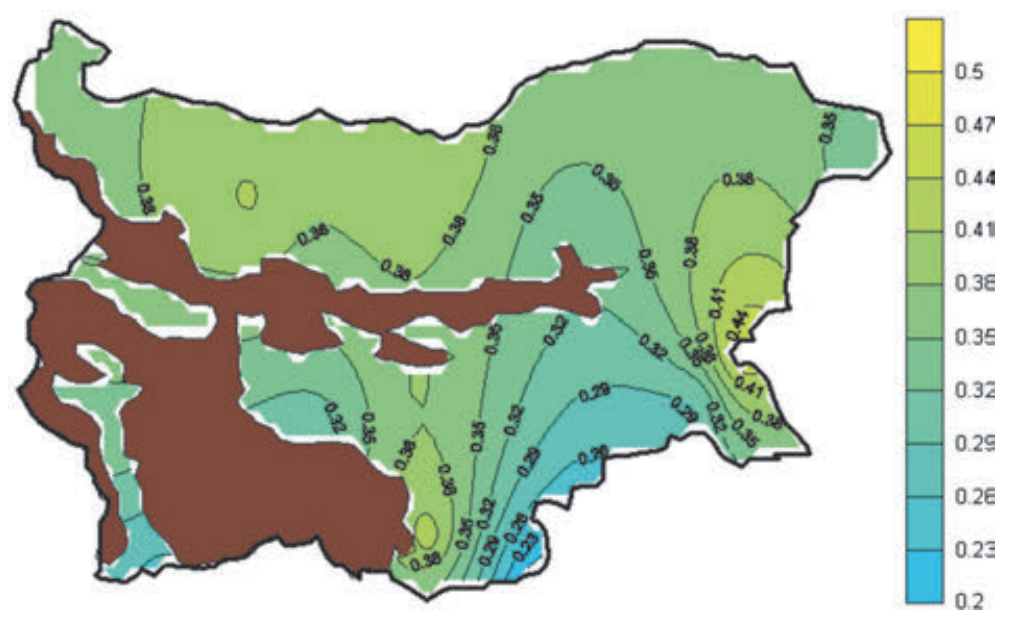

Figure 20. Distribution of CWSI values for the July-August periods of the years 1971-2000 inclusive; the brown colour denotes mountain regions (of altitudes above $1000 \mathrm{~m}$ ) not used in agriculture

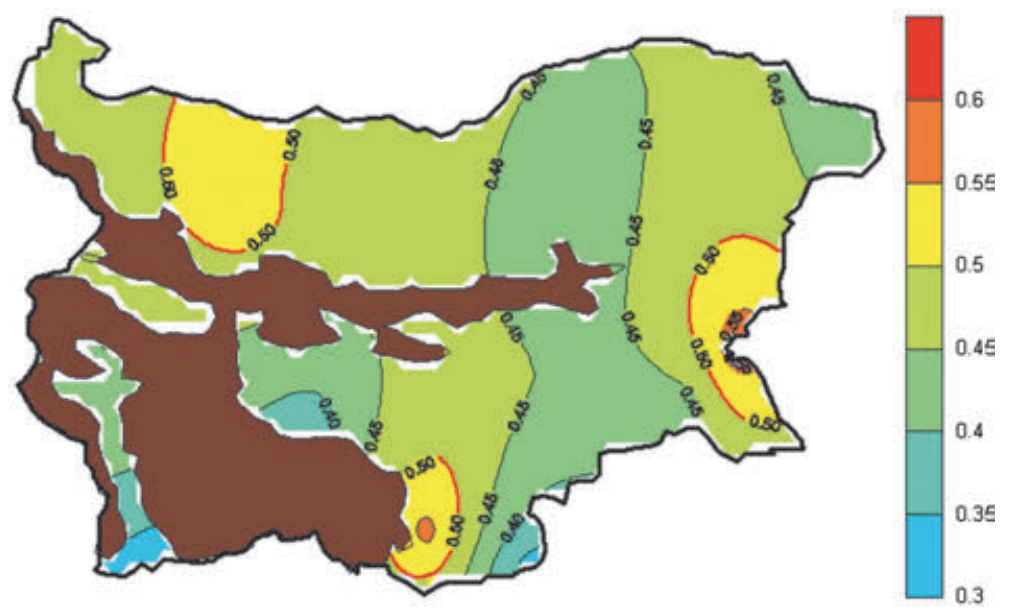

Figure 21. Distribution of CWSI values for the March-October periods of the years 1971-2000 inclusive; the brown colour denotes mountain regions (of altitudes above $1000 \mathrm{~m}$ ) not used in agriculture

The shortness of the observed Real Vegetation Period reflects a lack of soil moisture caused by higher temperatures, low rainfall totals, and intensive processes of evapotranspiration from crops. The vulnerability of agricultural crops to these phenomena is very marked where the duration of the vegetation period as a result of shortages of water falls to 90 days or less. On Bulgarian territory there are indeed regions in which meteorological conditions conspire to diminish the vegetation period to 90 days. A key and extensive area of this kind is Dobrudja in north-east Bulgaria; as well as the southern part of north-west Bulgaria in the foothill zone and Kazanlak (Fig. 22).

Simulated potential and water-limited yields for winter wheat show that lack of water can be a factor reducing yields from 50 to $200 \% \mathrm{~kg} / \mathrm{dka}$, particularly in eastern and south-central Bulgaria (Fig. 23-24). 


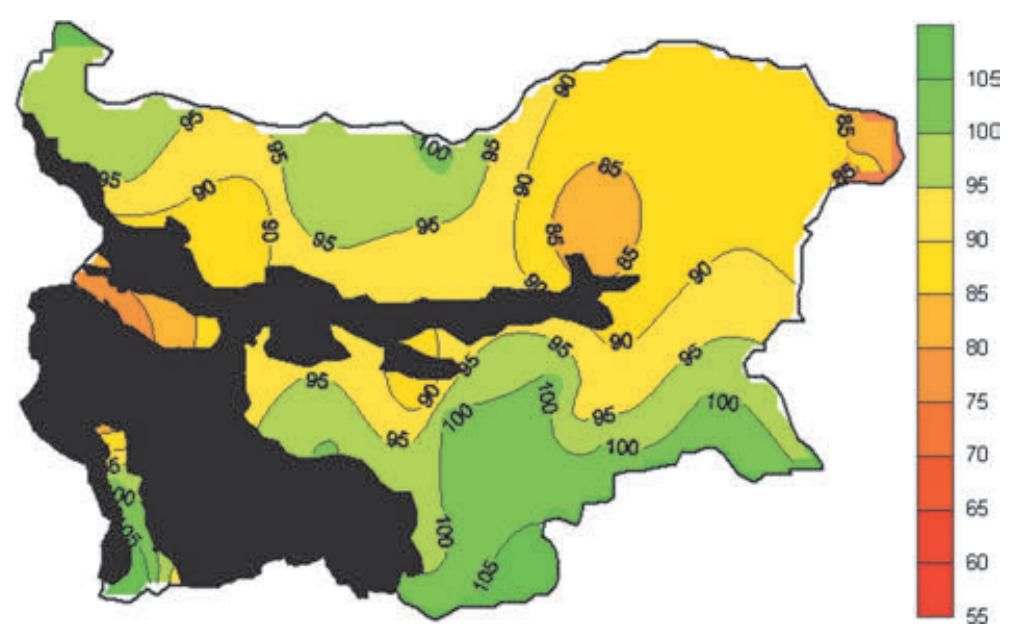

Figure 22. Reduction in the length of the Potential Vegetation Period as a result of shortfalls in soil moisture over the years 1971-2000. Durations $\leq 90$ days are not suitable, as crops cannot ripen. Marked in black are mountain regions (of altitudes above $1000 \mathrm{~m}$ ) which are not used in agriculture

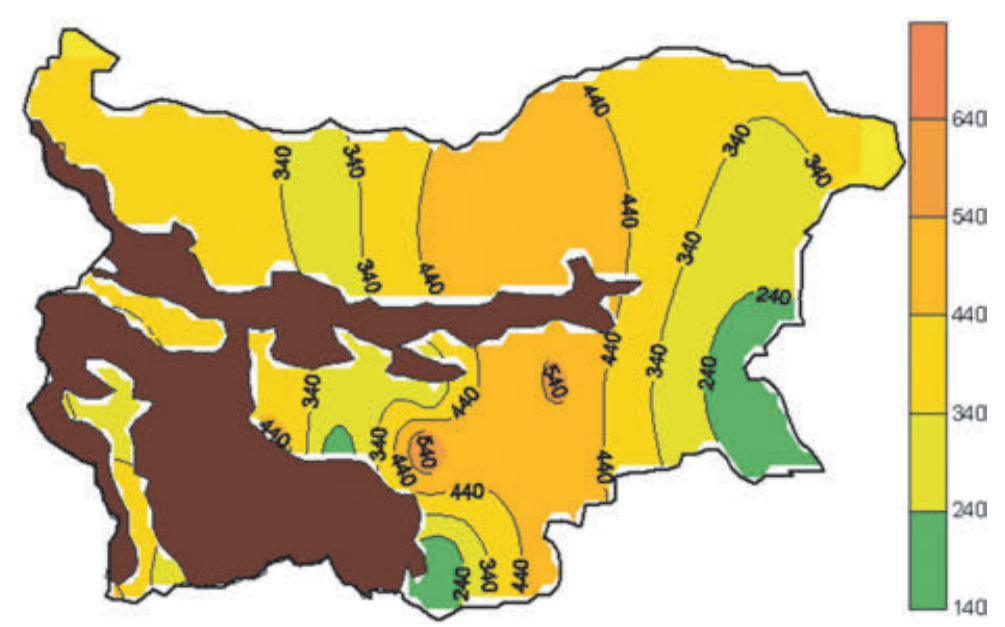

Figure 23. Long-term (1971-2000) spatial distribution for potential production of winter wheat in $\mathrm{kg} / \mathrm{dka}$. Marked in brown are mountain regions (of altitudes above $1000 \mathrm{~m}$ ) not used in agriculture 


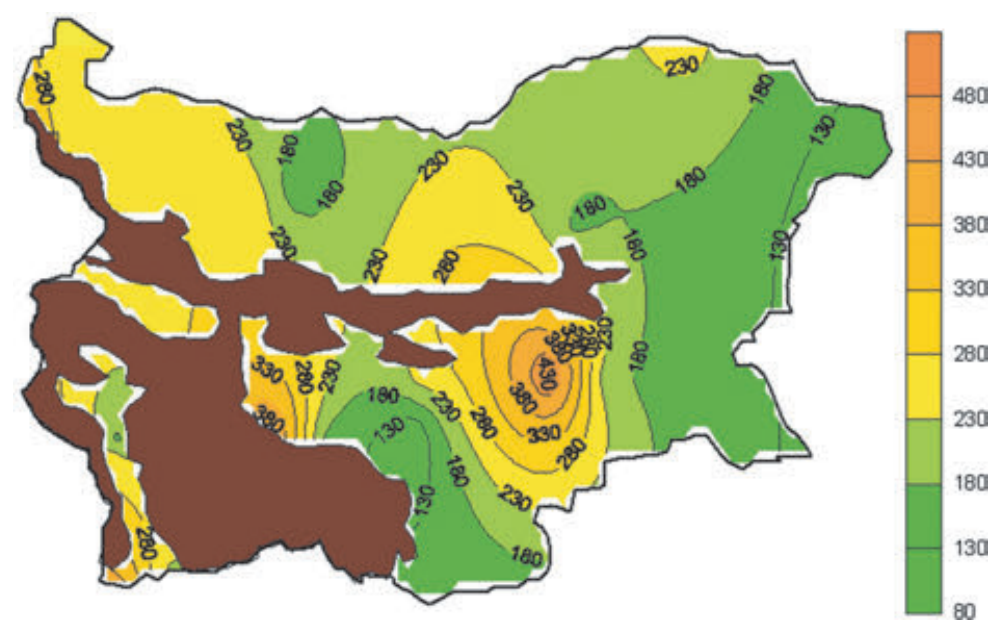

Figure 24. Long-term (1971-2000) spatial distribution of water-limitation of winter-wheat production expressed in $\mathrm{kg} / \mathrm{dka}$. Marked in brown are mountain regions (of altitudes above $1000 \mathrm{~m}$ ) not used in agriculture

On the basis of the hydrothermal conditions identified, it is possible to determine those regions that are suitable for the cultivation of soybeans. The threshold conditions for soybean crops to grow are the availability of $3500-3900^{\circ} \mathrm{C}$ degree-days of temperature and $500-550 \mathrm{~mm}$ of rainfall, if cultivation is to take place under natural conditions. The assessment of thermal conditions suggest that large areas of north-western and north-central Bulgaria, as well as parts of the south-west and south-east and almost the south-central part of Bulgaria do have appropriate thermal total (Fig. 25). However, when requirements as regards water are added in, the areas remaining suitable are seen to reduce significantly, though with the north-west, and parts of north-central and north-eastern Bulgaria are left as appropriate for the growing of soybeans under natural conditions (Fig. 26). An approach to zoning for agricultural crops on the basis of agroclimatic resources is thus demonstrated, and the same approach can of course be applied to all other types of crops, orchards and vineyards.

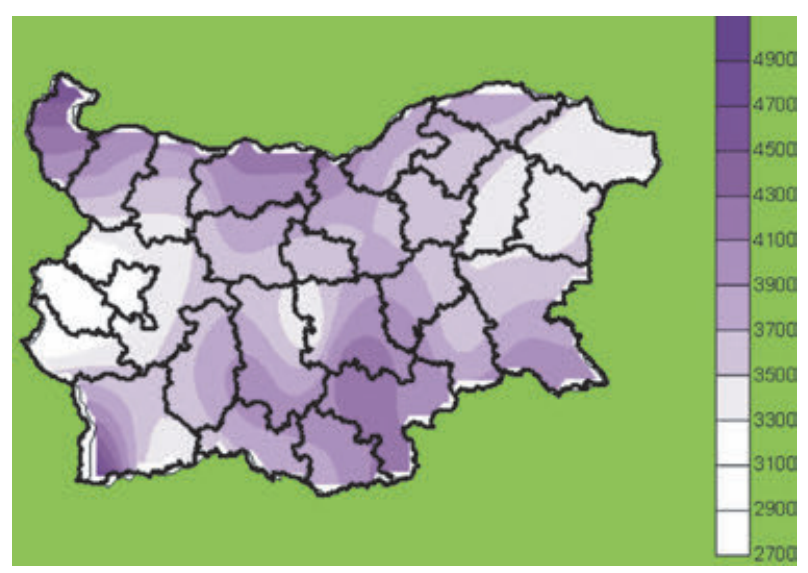

Figure 25. Soybean zoning in line with thermal conditions and the requirements of plants (in degree-days) 


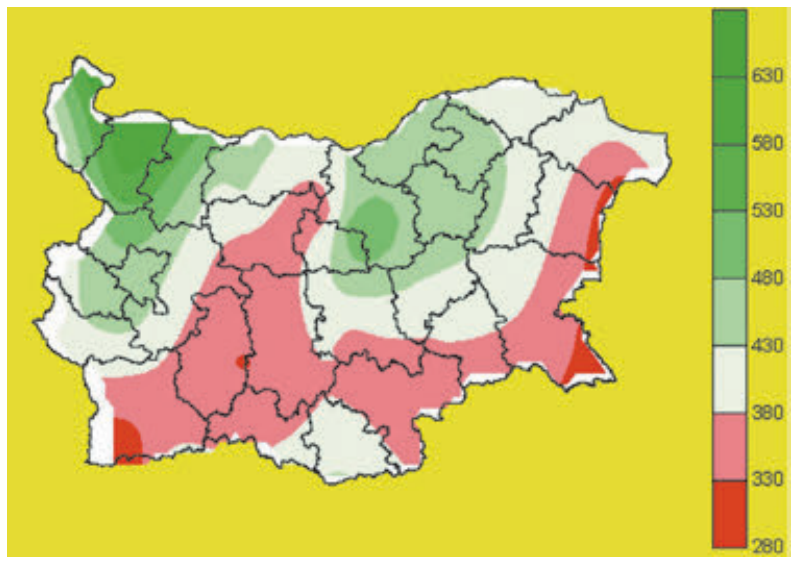

Figure 26. Soybean zoning in line with the moisture requirements of plants (in mm of rain)

\section{Conclusions}

- Agroclimatic conditions in Bulgaria are markedly varied, due to the influence of relief and specific features of climate.

- In the overall 1971-2000 period has seen average annual temperatures in Bulgaria increase by as much as $2.5^{\circ} \mathrm{C}$, in comparison with the beginning of the period, or $0.7^{\circ} \mathrm{C}$ in comparison with the reference period.

- Rainfall is also changing, as the quantity has decreased overall by $150 \mathrm{~mm}$ annually in comparison with the beginning of the aforementioned period, and by $40 \mathrm{~mm}$ in comparison with the reference period.

- The changes in climate referred to leave extensive areas of Bulgaria identifiable as characterised by conditions adverse to intensive farming. In line with the terminology of JRC, such areas may be called - Low Favourable regions (LFAs). If the consequences of climate change in these areas are to be mitigated, it will only be through additional investment by the farmers.

- In Bulgaria it is particularly necessary and urgent for measures to be developed to improve soil-moisture conditions. At the very least, there is a need for high-tech solutions as regards irrigation to be brought to bear during the parts of the growing season more crucial from the point of view of the ultimate yield.

\section{References}

Dunkel Z., 2009. Brief surveying and discussing of drought indices used in agricultural meteorology. Időjárás - Quarterly Journal of the Hungarian Meteorological Service, vol. 113, no. 1-2, pp. 23-37. Bański J., Błażejczyk K., 2006. Globalne zmiany klimatu i ich wptyw na rolnictwo. [in:] A. Kostrzewski, J. Czerniawska (ed.), Przemiany środowiska geograficznego Polski pótnocno-zachodniej, Poznań: Adam Mickiewicz University in Poznań, Bogucki Wydawnictwo Naukowe, pp. 119-129. Błażejczyk K., Żmudzka E., 2013. Globalne zmiany klimatu - spojrzenie po 25 latach prac IPCC. Kosmos, Problemy Nauk Biologicznych, vol. 62, no. 1, pp. 1-11. 
Brandani G., Natali F., Napoli M., Trombi G., Bindi M., Orlandini S., 2010. The water needs in agricultural sector in Tuscany, Italy. BALWOIS 2010 - Ohrid, Republic of Macedonia - 25-29 May 2010.

Dalla M.A., Grifoni D., Mancini M., Zipoli G., Orlandini S., 2011. The influence of climate on durum wheat quality in Tuscany, central Italy. International Journal of Biometeorology, vol. 55, no. 1, pp. 87-96.

Degórski M., 2000. The influence of possible climate change on soil structure in Poland. [in:] Globalnyje i regionalnyje izmienienia klimata $i$ ich prirodnyje i socjalno-ekonomiczeskije posledstwa, Moscow: GEOS, pp. 239-246.

Easterling W.E., Aggarwal P.K., Batima P., Brander K.M., Erda L., Howden S.M., Kirilenko A., Morton J., Soussana J.-F., Schmidhuber J., Tubiello F.N., 2007. Food, fibre and forest products. [in:] M.L. Parry, O.F. Canziani, J.P. Palutikof, P.J. van der Linden, C.E. Hanson (eds.), Climate Change 2007: Impacts, Adaptation and Vulnerability. Contribution of Working Group II to the Fourth Assessment Report of the Intergovernmental Panel on Climate Change, Cambridge: Cambridge University Press, pp. 273-313.

Kazandjiev V., Moteva M., Georgieva V., 2011. Near and far future hydro-thermal tendencies for crop growing in Bulgaria. $16^{\text {th }}$ International Water Technology Conference, Istanbul, Turkey.

Salinger M.J., Stigter C.J., Das H.P., 2000. Agrometeorological adaptation strategies to increasing climate variability and climate change. Agricultural and Forest Meteorology, vol. 103, pp. 167-184.

Trenberth K.E., 2011. Changes in precipitation with climate change. Climate Research, vol. 47, pp. 123-138. 
